\title{
Taxonomy of Educational Objectives in the Perspective of the Old Java Educational Theory: an Application to Holistic Education
}

\author{
Purwo Susongko \\ Universitas Pancasakti Tegal \\ \{purwosusongko@upstegal.ac.id\}
}

\begin{abstract}
The Old Java educational theory is a spiritual based educational theory, thus it may be made a framework of the application of holistic education. This study aims at describing the educational objectives in general and the taxonomy of educational objectives pursuant to the educational theory of Old Java and its application to holistic education. This study employed a hermeneutic method on the Old Java spiritual scripture, Sang Hyang Tatwa Jnana. The research result concludes that the general educational objectives according to the Old Java educational theory are weakening egoism, greed and hatred. The general educational achievement level according to the Old Java educational theory is to produce students with three levels of awareness, namely tamah (stable and tranquil), rajah (aggressive and full of motion) and satwa (sluggish and lazy). Taxonomy of educational objectives according to the Old Java educational theory consist of five domains, namely (1) awareness, (2) perception, (3) cognitive, (4) affective, and (5) psychomotor. Taxonomy of educational objectives according to the Old Java educational theory may be applied to formulate learning objectives well.
\end{abstract}

Keywords: Holistic Education, Old Java, Taxonomy, Educational Objectives

\section{Introduction}

Holistic education is one alternative educational philosophy which may solve moral, humanity and intellectuality issues in the current educational world. Holistic education attempts to involve student intellectually, physically, spiritually and emotionally and build relationship between student's external and internal worlds (1). From educator perspective, Miller (1997, 2000, 2005, 2006, and 2010) argues that holistic education also promotes the importance of teaching as a whole, covering individual's intellectual, emotional, physical, social, aesthetic and spiritual aspects and learning process (2).

Holistic education focuses on developing student's whole capabilities and encouraging student to be very good, which allows them to solve life problems and achieve life objectives (3). J Miller (2007) describes holistic education: The focus of holistic education is on relationships: the relationship between linear thinking and intuition, the relationship between mind and body, the relationships among various domains of knowledge, the relationship 
between the individual and community, the relationship to the earth and our relationship to our souls. (p. 13)

Likewise, J. Miller (2007) differentiates between holistic education which covers spiritual components and holistic education which covers multi-sensory experiences such as physique and social interaction (4). From the opinion, we may conclude that holistic education is based on spirituality development, thus it is capable of building student's competence in its entirety, both intellectual and moral capabilities.

There is difference in the meanings between spirituality, Soul and Religion. Gradle (2007) distinguishes between spirituality as a way of life and soul as "spiritual energy which is active, searching, mindfulness which puts all experiences into a holy world". Spirituality refers to practice, an element of philosophy, while soul is understood as a private place where we find wisdom, consolation, ourselves, God, love, and or relation with universal truth. Gradle (2007) explains religion as practice with "institution, acknowledgement of doctrine, and obedience to belief" (5). Holistic education attempts to develop student's spirituality together with intellectual and physical capabilities.

Holistic education is built and depends on educational process, not only it promotes positive attitude to learning, but also builds social skill needed to face current modern life (6), since Moral is more a product or effect than a cause. Moral as norm or a vision is not an instrument to settle morality improvement in education [7]. The behaviorists argue that moral formation must be performed with much learning treatment and experience [8]. To achieve the goals, holistic education must have a solid educational theoretical framework, thus its success may be identified, developed and evaluated on a practical level. Therefore, it requires spiritualism based educational theory to build a holistic education system.

The Old Java philosophy is a spiritual approach based philosophy system. Spirituality in Java mind realm is human behavior on the basis of weakening egoism [9]. With human's weakening egoism, life peace may be established not depending on religious or cultural view that one follows. With weakening egoism, human self-control will be performed better. Many researches show that a good self-control will influence a person's quality of morality $[10,11,12,13]$.

The Old Java philosophy is originated from the book Sang Hyang Tatwajnana which quite comprehensively explains the philosophy of Javanese human, morality and cosmology [14]. The author of Sanghyang Tatwajnana is still unknown until now, but it is expected to be composed between the $15^{\text {th }}$ and $16^{\text {th }}$ centuries or at the end of Majapahit Kingdom era [14]. Originated from the teaching of the book Sang Hyang Tatwajnana, the main ideas of the Old Java philosophy may be formulated and applied to the educational field. Susongko (2019) formulates some premises related to the application of the Old Java philosophy to the education as follows:

a. Human capability is not limited, covering physical, metaphysical and spiritual capability.

b. The dimension of student's capability covers five aspects, namely: (1) Buddhi (Awareness), (2) Citta (perception), (3) manah (cognitive), (4) Ahangkara (affective) and (5) Raga (psychomotor).

c. Each individual has initial (potential) or congenital (sattva, rajah and tamah characters) capability and actual capability developed through learning.

d. Psychomotor capability is the function of awareness, memory, cognitive and affective capabilities.

e. Samadhi (Meditation) is the method to concentrate one's mind in learning. [9]

Based on the formulation of Old Java educational philosophy, Susongko (2019) formulates the Old Java educational theory which explains some matters, such as learning objectives, 
learners, educational contents, learning strategies, teachers and domain of educational objectives[9]. The main objective of education according to the Old Java educational theory is to dismiss egoism, greed and hatred. Related to the taxonomy of educational objectives, the Old Java educational theory develops five domains that must be developed in educational process.

In the main objective aspect, there is significant difference between the Old Java main education objectives and the educational objectives according to other theories, particularly of perennial and liberal theories of education [15, 16]. Similarly, for the many domains developed in the taxonomy of educational objectives, there is difference with the taxonomy built so far by educational experts like Bloom and Marzano[17]. At a glance, the taxonomy of educational objectives according to the Old Java seems to be relatively comprehensive and may be applied to holistic education. How to define the five domains and the relationship between domains as well as how to apply them to learning in holistic education require further study. This study aims at: (1) Describing the general educational objectives according to the Old Java educational theory, (2) Describing the taxonomy of educational objectives according to the Old Java educational theory and its application in holistic education, and (3) Describing example of arranging learning objectives based on the taxonomy of learning objectives according to the Old Java educational theory.

\section{Method}

Pursuant to the objective, this study employed a hermeneutic method. Paul Ricoeur defines hermeneutics as a theory of operating understanding in interpreting a text [18]. Traditionally, Hermeneutics as a theory of interpretation (hermeneuein) may be understood in the sense to say, to explain, and to translate [19]. To say means expressing words, this means that reader inserts "expression" pursuant to his understanding of the context. To explain means explaining with emphasis on discursive understanding aspect. The third meaning is to translate. When a text is in a reader's language, collision between text world and the reader himself may be distracting. Translating is a special form of basic interpretative process which brings something to be understood [20].

Historically, Javanese spiritual culture is divided into three eras, namely Jawadipa, Jawa Budha/Old Java and Kejawen[14]. Jawadipa is Javanese original teaching and there is no solid reference of it until now besides Babad Kanung which is just released recently by Yayasan Kanung [21]. The form of Jawadipa culture may be viewed such as instruments in ceremonies in the form of tumpeng, belief in danghyang, worship of ancestral spirits, calculation of times in the form of wuku, windu, sluggishg, neptu dina, and some others. Jawa Budha or Old Java is Siva religious teaching which is mixed with Buddha Mahayana teaching plus Jawadipa teaching. The spiritual work of Old Java era includes Sang Hyang Tatwajnana, Sang Hyang Nawa Ruci, Sarasammuscaya, Slokantara, Vrati Sasana, Ganapati Tattwa, etc. [22]. Kejawen is Islamic tassawuf teaching mixed with Jawa Budha/Old Java teaching and there are a complete range of books available particularly at Surakarta and Yogyakarta Palaces.

The text used in this research is Rontal Sang Hyang Tatwajnana. The text has been retranslated and reinterpreted by Dhamar Sasangka into a book entitled Ilmu Jawa Kuno (Sanghyang Tatawajnana Nirmala Nawaruci) which was published by Gramedia in 2015. The rontal was kept and rewritten in Balinese language and writing by its teaching preservers in Bali. The book is the only translation of rontal as well as its comprehensive discussion, thus modern people may understand it. 
The researcher also employed analytical method in this study. The analysis was conducted by comparing the interpretation of text made by Dhamar Sasangka (2015) on the rontal Sang Hyang Tatwa Jnana and some literary sources of Buddhist philosophy, particularly with Abhidamma study and some sources of Siva philosophy such as book Sevaka Dharma and Tatwa Sang Hyang Mahajnana [23, 24, 25], since Buddhist and Siva philosophies greatly influence the Old Javanese people's mind realm (800 -1500 M).

\section{Result \& Discussion}

The research result starts with descriptive and analytical explanation of general educational objectives and the taxonomy of educational objectives according to the Old Java educational theory and its application to holistic education. In addition, it also discusses the application of taxonomy of Old Java educational objectives in learning.

\subsection{General Educational Objectives}

The general educational objective according to the Old Java educational philosophy is to dismiss egoism, greed, and hatred. Egoism is a high sense of ego; greed is dissatisfaction with what is owned; and hatred is a feeling of not liking when other is happy and a feeling of pleasure when other suffers. On the contrary, growing socialist mind, grateful of what is acquired and developing compassion is the basic awareness that must be continuously instilled in education, both in the process and result aspects. The special educational objective according to the Old Java educational theory, like other educational paradigms, is to develop thinking skill and action taking skill so as to be proficient in knowledge, both for oneself and in improvement of human civilization. This special objective will be developed to be the indicator of learning achievement which wholly forms a competence. Therefore, we may conclude that the general educational objective according to the Old Java theory is to improve the quality of spiritual learners. High spiritual quality will form an ever happy personality in one's life. This is in line with what is explained by Miller et al (2018) that holistic education prioritizes achievement of the country's goal of Gross National Happiness instead of merely the country's goal of Gross National Product [26].

The general educational objectives have a very important position since the quality of achieved special educational objectives greatly depends on the quality of awareness formed through the general objectives. Achieved general educational objectives will lead to three levels of awareness quality in the Old Java concept, namely Satva awareness, Rajah awareness and Tamah awareness with description of mental quality as presented in Table 1.

Table 1. Level of Achieved General Educational Objectives According to the Old Java Educational Theory

\begin{tabular}{|c|c|c|}
\hline Level & Indicator & Life Orientation \\
\hline $\begin{array}{l}\text { Satva: Stable } \\
\text { and Tranquil }\end{array}$ & $\begin{array}{l}\text { Full control of emotion, thought } \\
\text { and action; All good characters, } \\
\text { honesty and compliance with the } \\
\text { law, tolerance, tranquility, stable } \\
\text { intellect, not egoistic; Obtaining } \\
\text { knowledge, skill, meditating or } \\
\text { improving spiritual level; }\end{array}$ & $\begin{array}{l}\text { (1) Live by serving the society } \\
\text { without expecting reward or gift } \\
\text { or any hidden motive, (2) } \\
\text { Adiduniawi /true happiness }\end{array}$ \\
\hline Rajah: & Anger, jealousy, pride, egoism, & (1) Live with personal \\
\hline
\end{tabular}




\begin{tabular}{|c|c|c|}
\hline Level & Indicator & $\begin{array}{l}\text { Life Orientation } \\
\end{array}$ \\
\hline Aggressive and & bossy, seeking attention, greed, & improvement and achievement (2) \\
\hline Full of Motion & $\begin{array}{l}\text { full of ambition and worldly } \\
\text { desire, worry; not serious in } \\
\text { improving spiritual level; } \\
\text { Egocentric or having hidden } \\
\text { motive when helping others }\end{array}$ & $\begin{array}{l}\text { Obtaining power, worldly } \\
\text { properties, }\end{array}$ \\
\hline $\begin{array}{l}\text { Tamah: } \\
\text { Sluggish and } \\
\text { Lazy }\end{array}$ & $\begin{array}{l}\text { Lazy, inactive, depression, quite } \\
\text { egoistic, do not mind others or } \\
\text { even harm them when his egoistic } \\
\text { objective is not fulfilled, easily } \\
\text { getting angry; eating, drinking, } \\
\text { having sexual intercourse } \\
\text { excessively; }\end{array}$ & $\begin{array}{l}\text { (1) Often harm others for personal } \\
\text { progress (2) harm the public in } \\
\text { the name of certain religion or } \\
\text { ideology. }\end{array}$ \\
\hline
\end{tabular}

In the view of the Old Java theory, the quality of any competence of human greatly depends on their level of awareness, thus the awareness needs to be built continuously with various treatments. An individual with high science and technology capability and tamah awareness level will destroy human civilization. This is the basic principle, thus it is appropriate for the Old Java educational theory to be the framework of holistic education.

The Old Java Educational Theory introduces meditation as a method to develop awareness, both awareness in the sense of kesadaran jaga (awereness) and kesadaran kepahaman (consciousness). Learner's strong awareness leads to strong concentration capability in learning process, both in class and practice, which will be more effective. Since the last decade, many researches have been conducted on the effectiveness of meditation based learning model in Western countries. The framework of mediation as a learning model is discussed comprehensively by Slaghter HA, et al. (2007) [27]. It is also evident that meditation has also successfully encouraged student's productivity [28]. Yu Chen Ko, et al. (2015) further develop meditation based technology and prove the effectiveness of meditation method in improving English learning performance [29]. That meditation also positively influences employee's performance is also reported by some researches $[30,31]$. Even in the Middle East countries which are quite conventional, meditation has even been developed in learning at higher education level and is capable of improving student's high level thinking capability $[32,33]$.

\subsection{Taxonomy of Educational Objectives According to the Old Java Educational Theory}

In the view of the Old Java educational theory, there are five domains to be developed in educational process, thus educational assessment should also covers learner's success in the five aspects. The five domains are: (1) Buddhi (Awareness), (2) Citta (perception) (3) Manah (cognitive), (4) Ahangkara (affective) and (5) Raga (physique/psychomotor).

Awareness has the sense of kesadaran jaga (awareness) and kesadaran kepahaman (consciousness). Having an understanding of space and time, having wisdom and consideration are the indicator of having awareness. Awareness serves as a domain which greatly determines the success of learning since besides promoting learning spirit, it also determines one's concentration during learning process. Concentration is quite important since mind in the Old Java Philosophy is the sense which first responds to stimulus. Awareness, when applied to class learning, may have the meaning of learner's intrinsic motivation. 
Perception is the attention or a collection of all experiences a learner have. Perception is learner's past image or recording of all existing objects regarding lesson or teacher who teaches. Perception must always be built positive for successful learning. With learner's higher level of awareness quality, the arising perception will always supports it. Cognitive is the analytical, critical and logical thinking capability. This thinking capability is quite important since in the view of the Old Java theory, all stimuli incoming through human senses will be received by the mind first. Therefore, thinking capability is quite important related to the response that will be taken by an individual. Thinking quality and knowledge quality that a learner obtains greatly determine his quality of awareness.

Affective is a feeling of liking or disliking the existing stimulus or object. In the view of the Old Java theory, affective is greatly determined by learner's egoism level, that the lower the egoism, the more positive the feeling which emerges will be. It is here that the relation between awareness and affective may be observed. Psychomotor is the capability to perform a movement or action. Not all class learning measures the psychomotor dimension intensively. In sports, scientific and art subjects, the psychomotor dimension is intensively measured. Psychomotor in the Old Java Educational theory is the function of other domains, thus it is greatly influenced by four other domains of learning objectives.

The relation between each domain shows that moral quality cannot be separated from thinking capability or other practical capabilities. This is pursuant to the holistic education concept where all domains of student's capability are related and equal. Holistic education experience promotes more balanced development and grows relation between various individual aspects (intellectual, physical, spiritual, emotional, social and aesthetic), and relation between individual and others, individual and the environment, student's internal and external aspects [34].

For example, when ego raises and controls awareness, lame thoughts arise for personal benefit as we can see in both social relations between individuals and in organization or State world. Awareness may formulate the thoughts in detail for the sake of feeling. Feeling is not smart, but capable of forcing awareness to obey and satisfy what it desires. Mind is the leader of senses. All external information obtained by the eyes, ears, nose and skin enters through mind. The mind will then influence feeling, awareness and perception. All forms of experience entering the mind are responded by feeling, analyzed by awareness and saved as perception. From the explanation, each domain influences the other three domains except the psychomotor domain, which is influenced by the other four domains. The explanation of relation of the five domains may be viewed in Figure 1.

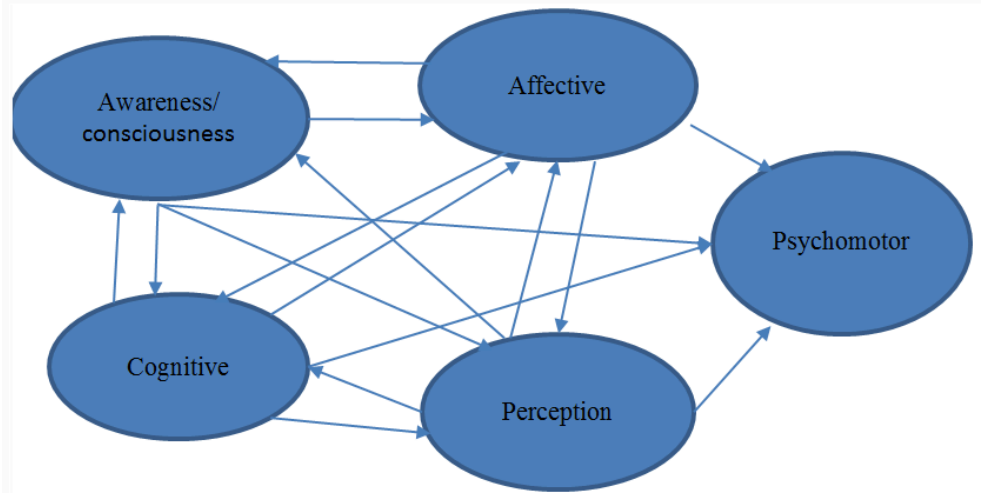

Fig 1. Relation between domains in the Taxonomy of Educational Objectives According to the Old Java Educational Theory 


\subsection{Arrangement of Learning Objectives Based on the Old Java Educational Theory}

The taxonomy of educational objectives according to the Old Java needs to be applied to class learning objectives. For clarity and differentiation of the five domains, below is an example of applications to Chemistry learning at Senior High School in Table 2.

Table 2. Example of Formulation of Learning Objectives Using the Taxonomy of Educational Objectives According to the Old Java

\begin{tabular}{|c|c|}
\hline $\begin{array}{l}\text { Basic } \\
\text { Competence }\end{array}$ & $\begin{array}{c}\text { Prove and Communicate the Application of Chemical } \\
\text { Basic Laws through Experiment }\end{array}$ \\
\hline Awareness & $\begin{array}{l}\text { With full attention and joy, students are fully aware that Chemistry is part of } \\
\text { science that all of its concepts need to be proven in real/empirically. }\end{array}$ \\
\hline Perception & $\begin{array}{l}\text { Students believe that it is easy to master Chemical Basic Laws through } \\
\text { Experiment }\end{array}$ \\
\hline Affective & $\begin{array}{l}\text { Students are pleased with laboratory practice to master the Chemical Basic } \\
\text { Laws }\end{array}$ \\
\hline Cognitive & Students master the Chemical Basic Laws comprehensively \\
\hline Psychomotor & $\begin{array}{l}\text { With careful observation, mind composure and spirit of a scientist, Students } \\
\text { may prove the Chemical Basic Laws through Laboratory Experiment }\end{array}$ \\
\hline
\end{tabular}

In the formulation of learning objectives using the taxonomy of educational objectives according to the Old Java, it is clear that domain awareness greatly influences the other domains. In spiritual language, an individual with high mind level with have all of his potentials directed towards the goodness of all people. Mind composure is greatly needed by learners in learning process, both in class and out of class, like laboratory observation. This is in line with the objective of holistic education, in which learner's practical capability should be integrated with student's moral prowess. Collaboration of science and spirituality has recently grown a new study, namely ultimate science. With spiritual knowledge basis, ultimate science tries to explain many scientific phenomena which cannot be explained through empirical observation [35].

\section{Conclusion}

General educational objectives according to the Old Java educational theory are spiritual based. The indicator of achieved objectives is weakening egoism, greed, and hatred. The general educational achievement according to the Old Java educational theory produces students with three levels of awareness, namely Satwa (stable and tranquil), Rajah (aggressive and full of motion) and Tamah (sluggish and lazy). The taxonomy of educational objectives according to the Old Java educational theory consists of five domains, namely (1) Awareness, (2) Perception (3) cognitive, (4) affective, and (5) psychomotor. Each domain influences three other domains, except the psychomotor domain, which is influenced by the other four domains. The taxonomy of educational objectives according to the Old Java educational theory may be applied to formulate learning objectives well. The taxonomy of educational objectives according to the Old Java educational theory may become the framework to arrange holistic education objectives.

\section{References}


[1] Dutton, S. E. (2015). Education in and by rhythm: Exploring holistic experiences in Dalcroze pedagogy (Doctoral dissertation).

[2] Preston, J. P. (2012). Holistic education: A pioneer narrative. LEARNing Landscapes, 5(2), 251-267.

[3] Iyer, R. B. (2015). Blending East and West for holistic education. Educational Research and Reviews, 10(3), 244-248.

[4] Miller, J. P. (2007). The holistic curriculum (2nd ed.). Toronto, ON: University of Toronto Press.

[5] Gradle, S. (2007). Spiritual ecology in art education: A re-vision of meaning. In L. Bresler (Ed.), International Handbook of Research in Arts Education (pp. 1501-1516). Dordrecht, NL: Springer.

[6] Hare, J. (2010). Holistic education: An interpretation for teachers in the IB programmes. International Baccalaureate.

[7] Wahib , A (2002). Pergolakan pemikiran Islam (catatan harian).Jakarta:LP3ES

[8] Killen, M., \& Smetana, J. G. (2015). Origins and development of morality. Handbook of child psychology and developmental science, 1-49.

[9] Susongko, P. (2019). Konstruksi Teori Pendidikan Berbasis Filsafat Jawa Kuno (Studi Analisis Dokumenter Berdasarkan Kitab Sang Hyang Tatwa Jnana Dan Sang Hyang Nawa Ruci). Cakrawala: Jurnal Pendidikan, 13(1), 73-88.

[10] Wikström, P. O. H., \& Svensson, R. (2010). When does self-control matter? The interaction between morality and self-control in crime causation. European Journal of Criminology, 7(5), 395-410.

[11] Svensson, R., Pauwels, L., \& Weerman, F. M. (2010). Does the effect of self-control on adolescent offending vary by level of morality? A test in three countries. Criminal Justice and Behavior, 37(6), 732-743.

[12] Bertok, E., \& Meško, G. (2013). Self-Control and Morality in Slovenian Primary and Secondary School Sample: The Results of YouPrev Study. Varstvoslovje: Journal of Criminal Justice \& Security, 15(4).

[13] Barton-Crosby, J., \& Hirtenlehner, H. (2020). The Role of Morality and Self-Control in Conditioning the Criminogenic Effect of Provocation. A Partial Test of Situational Action Theory. Deviant Behavior, 1-22.

[14] Dhamar Shasangka.(2015). Ilmu jawa kuno , sang hyang tatwajnana nirmala nawaruci Jakarta: Dolphin

[15] Maftoon, P., \& Shakouri, N. (2013). On situating the stance of perennialism in the history of curriculum development in Iran: A philosophical look. International Journal of Language Learning and Applied Linguistics World, 3(4), 55-64.

[16] Thompson, W. C. (2017). Liberalism in Education. In Oxford Research Encyclopedia of Education.

[17] Irvine, J. (2017). A Comparison of Revised Bloom and Marzano's New Taxonomy of Learning. Research in Higher Education Journal, 33. Sönmez, V. (2017). Association of Cognitive, Affective, Psychomotor and Intuitive Domains in Education, Sönmez Model. Universal Journal of Educational Research, 5(3), 347-356.

[18] Ricoeur, Paul, Hermeneutics and The Human Sciences, (terj.) Hermeneutika Ilmu-ilmu Sosial, Yogyakarta: Kreasi Wacana, 2008.

[19] Stolze, R. (2011). The translator's approach: Introduction to translational hermeneutics: Theory and examples from practice (Vol. 41). Frank \& Timme GmbH.

[20] Zimmermann, J. (2015). Hermeneutics: A very short introduction. OUP Oxford. 
[21] Sigit Wibowo \& Eko Teguh Widodo (2016). Sejarah perjalanan orang Jawa ( 230 SM1292). Jakarta: Yayasan Jawa Kanung

[22] Anand Krisna.(2015). Dvipantara dharma sastra.Jakarta: Centre for Vedic \& Dharmic Studies

[23] Bodhi, B. (2012). Comprehensive Manual of Abhidhamma: The Abhidhammattha Sangaha. Pariyatti Publishing.

[24] Windya, I. M. (2020). AJARAN PEMBEBASAN DALAM LONTAR SANGHYANG MAHÃJ̃̃ANA. Jñānasiddhânta: Jurnal Teologi Hindu, 2(1).

[25] Krishna, A. (2015). Dvipantara Dharma Sastra: Ancient Indonesia Wisdom for Modern Times Kebajikan Kuna Nusantara untuk Masa Kini; Sara-Samuscaya, Sloka, Sevaka Dharma (ME Suparyasa, I. Elstner, B. Giorgio, \& A. Colbert. Centre for Vedic and Dharmic Studies.

[26] Miller, J. P., Nigh, K., Binder, M. J., Novak, B., \& Crowell, S. (Eds.). (2018). International handbook of holistic education. Routledge.

[27] Slaghter HA et al.(2007). Learning to pay attention. Journal of Plos Biology. 6 (3).1188-1189

[28] Rick Dogsai. (2013). A Mindful approach to learning.Journal of The Futurist.8-10.

[29] Yu-Chen Kuo, Hui Chun, dan Chien Je Chen. (2015). An English Listening learning system based on brainwave meditation recognition technology. Int'l Coef e learning,eBus,EIS and e-Gov

[30] Li An Ho. (2011). Meditation, learning,organizational innovation and performance.Journal of Industrial Management \& Data System, 111(1).113-131

[31] William, G (2011).Deeper mindfulness for better work performance. Civil Engineering: Magazine of the south African Institution of civil Engineering .8.

[32] Basim, Aldhahadha .(2013). The effect of muslim praying meditation and transcendental meditation programs on mindfulness among the university of nizwa Students.College Students Journal.668-676.

[33] Yassir, M.M \& Faisal,MW.(2014). Using meditation and reflection in the un iverse leads to enhance of creation and creativity for higher education students.European Scientific Journal. 10 (13). 268-280

[34] Mahmoudi, S., Jafari, E., Nasrabadi, H. A., \& Liaghatdar, M. J. (2012). Holistic education: An approach for 21 century. International Education Studies, 5(2), 178-186.

[35] Trizio, E. (2019). 19 Husserl's early concept of metaphysics as the ultimate science of reality. The New Yearbook for Phenomenology and Phenomenological Philosophy: Volume 17. 